\title{
ПОШИРЕНІСТЬ ТРИВОЖНИХ ТА ДЕПРЕСИВНИХ РОЗЛАДІВ У ВІЙСЬКОВОСЛУЖБОВЦІВ-УЧАСНИКІВ АНТИТЕРОРИСТИЧНОї ОПЕРАЦІї
}

\begin{abstract}
Резюме. В умовах проведення антитерористичної операції на усіх її учасників впливає комплекс інтенсивних тривало діючих стресогенних чинників, що призводить до напруження адаптаційних систем організму.

Мета дослідження - вивчити поширеність тривожних та депресивних розладів у військовослужбовців-учасників антитерористичної операції (АТО).

Матеріали і методи. Методом випадкової вибірки проведено анонімне опитування з використанням Госпітальної шкали тривоги і депресії (HADS) 120 військовослужбовців-учасників антитерористичної операції, які лікувались в умовах денного стаціонару Клініки амбулаторної допомоги Національного військово-медичного клінічного центру ГВКГ. Дослідну групу склали чоловіки, середній вік $(40,8 \pm 0,67)$ року. В дослідженні використано бібліографічний, аналітичний та системний підходи.

Результати досліджень та їх обговорення. У військовослужбовців-учасників АТО встановлено високу поширеність $(40,8 \pm 4,5)$ \% тривожно-депресивних розладів (тривожні - $(35,0 \pm 4,4) \%$, депресивні - $(24,1 \pm 3,9) \%$ (при р>0,05)) та відсутність статистично достовірної різниці ( $>0,05)$ щодо поширеності тривожних та депресивних розладів між групами 3 артеріальною гіпертензією (АГ) та без АГ, з АГ І ст. та АГ ІІ ст.

Висновки. Отримані результати дослідження вимагають запровадження комплексу заходів щодо попередження, діагностики та корекції тривожних та депресивних розладів у військовослужбовців-учасників АТО.
\end{abstract}

Ключові слова: тривожні; депресивні розлади; військовослужбовці-учасники антитерористичної операції.

ВСТУП В умовах проведення антитерористичної операції (АТО) на всіх її учасників впливає комплекс інтенсивних тривало діючих стресогенних чинників, що призводить до напруження адаптаційних систем організму $[3,4]$. Адже при дії екстремальних чинників реакція адаптації завжди $є$ надлишковою [1]. Таким чином, профресійна діяльність військовослужбовців у зоні проведення бойових дій пов'язана з психоемоційним перенавантаженням, що сприяє розвитку хронічного стресу та негативно впливає на стан здоров'я, сприяє розвитку та прогресуванню захворювань [2, 3].

МАТЕРІАЛИ I МЕТОДИ Методом виПадкової вибірки було проведено анонімне опитування з використанням Госпітальної шкали тривоги і депресії (HADS) 120 військовослужбовців-учасників АТО, які лікувались в умовах денного стаціонару Клініки амбулаторної допомоги (КАД) Національного військово-медичного клінічного центру (НВМКЦ) ГВКГ. Дослідну групу склали чоловіки, середній вік яких $(40,8 \pm 0,67)$ року. Для фрормування бази даних і статистичної обробки результатів використано програму Microsoft Excel 2007. Статистичний аналіз отриманого матеріалу проводили за допомогою пакета прикладних програм методами варіаційної статистики із використанням t-критерію Стьюдента. Для змінних найменувань та рангових змінних первинна обробка включала в себе розрахунок відсотків. У дослідженні використано бібліограсрічний, аналітичний та системний підходи.
РЕЗУЛЬТАТИ ДОСЛІДЖЕНЬ ТА ЇХ ОБГОВОРЕННЯ Проведені дослідження показали, що загалом депресивні та/або тривожні розлади виявлено у $(40,8 \pm 4,5) \%$ військовослужбовців-учасників АТО (табл. 1), що значно перевищує результати отримані при обстеженні військовослужбовців Київського гарнізону, які проходили поглиблений медичний огляд у 2010 р. - $(25,0 \pm 2,8) \%(p<0,01)$.

Необхідно зауважити, що у військовослужбовців-учасників АТО виявлено високу частоту як тривожних $(35,0 \pm 4,4) \%$, так і депресивних розладів - $(24,1 \pm 3,9) \%$ (при р>0,05).

Для визначення особливостей впливу артеріальної гіпертензії (АГ) на частоту виявлення тривожних і депресивних розладів, обстежених військовослужбовців поділили на дві групи. До першої групи увійшли 53 військовослужбовці-учасники АТО (середній вік $(40,0 \pm 1,1)$ року) з соматичною патологією без АГ, в другу групу - 67 військовослужбовців-учасників АТО з АГ (середній вік $(41,5 \pm 0,9)$ року, при р>0,05). Поділ військовослужбовцівучасників АТО за наявністю депресивних та/або тривожних розладів представлено в таблиці 2.

Таким чином, було встановлено високу поширеність як тривожних, так і депресивних розладів в обох досліджуваних групах, проте порівняльний аналіз не виявив статистично достовірної різниці $(p>0,05)$ між групами щодо поширеності тривожних та депресивних розладів у військовослужбовців-учасників АТО з АГ та без АГ.

Таблиця 1. Тривожні та депресивні розлади у військовослужбовців-учасників антитерористичної операції (за шкалою HADS)

\begin{tabular}{|c|c|c|}
\hline \multirow{2}{*}{ Характеристика тривоги та депресії за шкалою HADS } & \multicolumn{2}{|c|}{$\begin{array}{l}\text { Виявлено у військовослужбовців-учасників АТО } \\
(\mathrm{n}=120)\end{array}$} \\
\hline & абс. число & $\%$ \\
\hline Субклінічна тривога & 31 & $25,8 \pm 4,0$ \\
\hline Клінічно виражена тривога & 11 & $9,2 \pm 2,6$ \\
\hline Субклінічна та клінічно виражена тривога & 42 & $35,0 \pm 4,4$ \\
\hline Субклінічна депресія & 11 & $9,2 \pm 2,6$ \\
\hline Клінічно виражена депресія & 18 & $15 \pm 3,3$ \\
\hline Субклінічна та клінічно виражена депресія & 29 & $24,1 \pm 3,9$ \\
\hline Поєднання тривожних та депресивних розладів & 20 & $16,7 \pm 3,4$ \\
\hline
\end{tabular}


Таблиця 2. Тривожні та депресивні розлади у військовослужбовців-учасників антитеростичної операції без артеріальної гіпертензії (перша група) та з артеріальною гіпертензією (друга група) (за шкалою HADS)

\begin{tabular}{|l|c|c|c|c|}
\hline \multirow{2}{*}{$\begin{array}{c}\text { Характеристика тривоги та депресії за шкалою } \\
\text { HADS }\end{array}$} & \multicolumn{3}{|c|}{ Виявлено у військовослужбовів-учасників АТО } \\
\cline { 2 - 5 } & \multicolumn{2}{|c|}{ перша група (n=53) } & $\%$ & \multicolumn{2}{|c|}{ друга група (n=67) } \\
\cline { 2 - 5 } & абс. чис. & $22,6 \pm 5,7$ & 19 & $28,4 \pm 5,5$ \\
\hline Субклінічна тривога & 12 & $7,5 \pm 3,6$ & 7 & $10,4 \pm 3,7$ \\
\hline Клінічно виражена тривога & 4 & $30,2 \pm 6,3$ & 26 & $38,8 \pm 6,0$ \\
\hline Субклінічна та клінічно виражена тривога & 16 & $7,5 \pm 3,6$ & 7 & $10,4 \pm 3,7$ \\
\hline Субклінічна депресія & 4 & $13,2 \pm 4,6$ & 11 & $16,4 \pm 4,5$ \\
\hline Клінічно виражена депресія & 7 & $20,8 \pm 5,6$ & 18 & $26,9 \pm 5,4$ \\
\hline Субклінічна та клінічно виражена депресія & 11 & $17,0 \pm 5,2$ & 10 & $14,9 \pm 4,4$ \\
\hline Поєднання тривожних та депресивних розладів & 9 & & & 7 \\
\hline
\end{tabular}

Також ми не отримали статистично достовірної різниці ( $>0,05)$ і у військовослужбовців-учасників АТО з АГ I та II стадіями: відповідно у 31,9 та 24,6 \%.

ВИсновки Враховуючи високу частоту виявлення тривожних і депресивних розладів у військовослужбовцівучасників АТО, важливим є запровадження комплексу заходів щодо попередження, діагностики та корекції у них тривожних та депресивних розладів. 3 цією метою необ- хідно підвищувати поінформованість військовослужбовців щодо набуття вмінь психологічної самодопомоги та проорілактики негативного впливу стресу.

Перспективи подальших досліджень Плануємо запровадити в роботу КАД НВМКЦ ГВКГ комплекс заходів із метою підвищення поінформованості військовослужбовців щодо тривожно-депресивних розладів, своєчасного виявлення лікарями відповідних розладів та їх корекції.

\section{СПИСОК ЛІТЕРАТУРИ}

1. Єна А. І. Актуальність і організаційні засади медико-психологічної реабілітації учасників антитерористичної операції / А. І. Єна, В. В. Маслюк, А. В. Сергієнко // Науковий журнал МОЗ України. - 2014. - № 1. - С. 5-16.

2. Коваль С. М. Стрес-індукована артеріальна гіпертензія та артеріальна гіпертензія військового часу - грізні виклики сучасній Україні / С. М. Коваль, О. І. Снугурська // Артеріальна гіпертензія. - 2015. - № 5 (43). - С. 13-18.
3. Кундієв Ю. І. Напруженість праці як фрактор професійного стресу та ризику здоров'ю / Ю. І. Кундієв, В. І. Чернюк, В. М. Шевцова // Український журнал з проблем медицини праці. - 2005. - № 3-4. - С. 90-98.

4. Трущелев С. А. О совершенствовании охраны психического здоровья военнослужащих / С. А. Трущелев // Военно-медицинский журнал. - 2010. - № 2. - С. 39-42.

\section{PREVALENCE OF ANXIETY AND DEPRESSIVE DISORDERS AMONG MILITARY PERSONNEL WHO HAD PARTICIPATED IN THE} ANTITERRORIST OPERATION

Summary. All participants of the antiterrorist operation are influenced by a complex of intense long-acting stressors leading to the strain of adaptive systems of the body.

The aim of the study - to investigate the incidence of anxiety and depressive disorders among military personnel who had participated in the antiterrorist operation.

Materials and Methods. An anonymous survey of 102 military personnel who had participated in the antiterrorist operation introduced in the day care center of Outpatient Clinic Department at the National Military Medical Clinical Center "The Main Military Clinical Hospital" has been done. The hospital anxiety and depression scale (HADS) has been use to identify anxiety and depressive disorders. The study group includes men, the middle age is $(40.8 \pm 0.67)$ years. Methods of investigation are bibliographical, information-analytical and system approach.

Results and Discussion. It is established that among personnel who had participated in the antiterrorist operation revealed a high prevalence $(40.8 \pm 4.5 \%)$ of anxiety-depressive disorders (anxious - $(35.0 \pm 4.4) \%$, depressive $-(24.1 \pm 3.9) \%(p>0.05)$ ) and the absence of a statistically significant difference ( $p>0.05$ ) with respect to the prevalence of anxiety and depressive disorders between groups with arterial hypertension $(\mathrm{AH})$ and without $\mathrm{AH}$, with $\mathrm{AH}$ stage I and $\mathrm{AH}$ stage II.

Conclusions. The results of the research require the introduction of a set of measures to prevent, diagnose and correct anxious and depressive disorders among military who had participated in the antiterrorist operation.

Key words: anxiety; depressive disorders; military people. 


\section{РАСПРОСТРАНЕННОСТЬ ТРЕВОЖНЫХ И ДЕПРЕССИВНЫХ РАССТРОЙСТВ У ВОЕННОСЛУЖАЩИХ-УЧАСТНИКОВ АНТИТЕРРОРИСТИЧЕСКОЙ ОПЕРАЦИИ}

Резюме. В условиях проведения антитеррористической операции на всех ее участников влияет комплекс интенсивных длительно действующих стрессогенных фракторов, что приводит к напряжению адаптационных систем организма.

Цель исследования - определить частоту выявления тревожных и депрессивных расстройств у военнослужащих-участников АТО.

Материалы и методы. Методом случайной виборки проведен анонимный опрос с использованием Госпитальной шкалы тревоги и депрессии (HADS) 120 военнослужащих-участников ATO, которые лечились в условиях дневного стационара Клиники амбулаторной помощи Национального военно-медицинского клинического центра ГВКГ. Исследуемую группу составили мужчины, середний возраст $(40,8 \pm 0,67)$ лет. В исследовании использованы библиограсический, инсрормационно-аналитический, статистический методы анализа.

Результаты исследований и их обсуждение. У военнослужащих-участников АТО выявлено высокую распространенность $(40,8 \pm 4,5) \%$ тревожно-депрессивных расстройств (тревожные - $(35,0 \pm 4,4) \%$, депрессивные - $(24,1 \pm 3,9) \%(п р и ~ р>0,05))$ и отсутствие статистически достоверной разницы (р>0,05) в отношении распространенности тревожных и депрессивных расстройств между группами с артериальной гипертензией (АГ) и без АГ, с АГ І ст. и АГ ІІ ст.

Выводы. Полученные результаты исследования требуют внедрения комплекса мероприятий по предупреждению, диагностике и коррекции тревожных и депрессивных расстройств у военнослужащих-участников АTO.

Ключевые слова: тревожные; депрессивные расстройства; военнослужащие-участники антитеррористической операции. 